\title{
Defending Nietzsche's Constructivism about Objects
}

\author{
Justin Remhof
}

\begin{abstract}
Nietzsche appears to adopt a radical Kantian view of objects called constructivism, which holds that the existence of all objects depends essentially on our practices. This essay provides a new reconstruction of Nietzsche's argument for constructivism and responds to five pressing objections to reading Nietzsche as a constructivist that have not been addressed by commentators defending constructivist interpretations of Nietzsche.
\end{abstract}

In the tradition of Kant and post-Kantian philosophy, Nietzsche was attentive to questions concerning the nature of objects. His texts often address questions concerning the existence and non-existence of objects, the relation of objects to human minds, and how different views of objects impact commitments in many areas of philosophy—not just metaphysics but also epistemology, semantics, science, and even ethics. I have argued (Remhof 2015a), along with Nehamas (1985: Ch. 3), Anderson (1998), and Cox (1999: 152-163), that Nietzsche adopts a radical Kantian view of objects called constructivism. ${ }^{1}$ This view holds that all objects are socially constructed. Specifically, the existence of all objects we can encounter, such as rocks, trees, and planets, depends essentially on the application of concepts to the world relative to our needs, interests, and values. Nietzsche writes that 'A "thing" is the sum of its effects, synthetically united by a concept' [Ein 'Ding' ist die Summe seiner Wirkungen, synthetisch gebunden durch einen Begriff] (KSA 13:14[98]), and asserts that 'it is enough to create new names [...] in order to create new "things"' [es genügt, neue Namen [...] um auf die Länge hin neue 'Dinge' zu schaffen] (GS 58, see also KSA 12:2[77], 2[150]). 'Thing' is presumably scare-quoted because constructivism is unorthodox. After all, commonsense intuition strongly suggests that many objects are not socially constructed. But I am not concerned with the truth of constructivism here. Rather, my primary aim is to address objections to reading Nietzsche as a constructivist about objects, specifically objections that other constructivist readers have overlooked.

The paper unfolds as follows. I first provide a new reconstruction of Nietzsche's argument for constructivism. The bulk of the essay then addresses five problems with reading Nietzsche as a constructivist. Briefly, here are the objections. First, in a famous passage, Nietzsche appears to embrace the eliminativist view that objects do not exist. Second, constructivism appears to involve taking the world to have human features, and Nietzsche is famously critical of anthropomorphism. Third, if constructivism were true, then, given the diversity of language users, 
some group of people might construct objects that other groups deny exist, which could result in contradiction. Fourth, it appears obvious that some objects are unconstructed, such as those we have not encountered and those that existed before human beings. Since constructivism claims that all objects are constructed, it appears that constructivism is false. Finally, constructivism holds that subjects bring objects into existence, but subjects also seem to be proper candidates for construction. It then looks like subjects must somehow bring themselves into existence, which is viciously circular. If any of these objections are sound, there could be good reason to reject Nietzsche's constructivism. My aim is to show none are, in fact, sound.

\section{Nietzsche's Argument for Object Constructivism}

First, consider Nietzsche's constructivism about objects. When referring to an object, Nietzsche follows common German usage by employing 'Ding' more often than 'Objekt', but the two are interchangeable. Both refer to concrete objects we commonly experience in everyday life, such as trees and leaves, cats and dogs, and tables and chairs. For purposes of this paper, then, I concentrate on Nietzsche's understanding of concrete objects that populate our everyday world.

Nietzsche's view that all objects are socially constructed means that we bring all objects into existence. ${ }^{3}$ Here is my reconstruction of his argument ${ }^{4}$ :

(CV1) Only bundles of forces exist.

(CV2) If so, then if objects exist, they are identical to unified bundles of forces.

(CV3) Objects exist.

(CV4) So, objects are identical to unified bundles of forces.

(CV5) Bundles of forces are unified by virtue of human practices.

(CV6) So, objects are identical to bundles of forces unified by virtue of human practices.

(CV7) If so, then human practices bring all objects into existence.

(CV8) So, human practices bring all objects into existence.

The argument, which is valid, moves from Nietzsche's ontology to constructivism about objects. Why accept the premises? The first is justified by Nietzsche's fundamental ontology, which he describes as 'will to power'. The will to power ontology holds that the world is comprised of bundles of forces. Many commentators believe that Nietzsche is committed to such an ontology, especially those concerned with Nietzsche's metaphysics, ${ }^{5}$ but the reading is not uncontroversial. ${ }^{6}$ In support of CV1, consider the following. Nietzsche writes that 'the world viewed from inside [...] would be "will to power" and nothing else' (BGE 36). He claims that 'nature' could be read as operating according to 'will to power', the idea that 'every power draws its ultimate consequences at every moment' (BGE 22). He says that we live in 'a world whose essence [Essenz] is will 
to power' (BGE 186) and that 'in all events a power-will is operating' (GM II: 12). Nietzsche appeals to will to power as an explanatory principle for the natural world in a wide range of contexts in both published and unpublished writingstoo many, in fact, to review here. ${ }^{7}$ For these reasons, I will proceed on the assumption that Nietzsche endorses the will to power ontology. For Nietzsche, reality consists in bundles of forces.

Now turn to CV2, which holds that if only bundles of forces exist, then, if objects exist, they are identical to unified bundles of forces. If the existence of objects were not identical to bundles of forces, then it would not be the case that only bundles of forces exist. The thought that objects are unified bundles of forces captures the idea that objects such as rocks, trees, and planets are particular organizations of forces that are bound together. Objects are 'complexes of events', where a 'complex' is an organized unit of interacting forces (KSA 12:9[91]). Given the plausible assumption that middle-size concrete objects are composite, or composed of at least two forces, rather than mereologically simple, it follows that forces considered by themselves, or apart from unification with other forces, are not proper candidates for the ultimate constituents of concrete objects. Forces considered in bundles ultimately compose concrete objects.

CV3 holds that objects exist. This could actually be considered controversial. Commentators who believe Nietzsche endorses eliminativism would deny this premise. ${ }^{8}$ Below, I defend CV3 from that challenge. Here, it will be sufficient simply to point out that Nietzsche nearly always assumes that objects exist. For example, he writes, 'Just as little do we see a tree exactly and completely with reference to leaves, twigs, color, and form; it is so very much easier for us simply to improvise some approximation of a tree' (BGE 192). And he claims, 'He, for instance, who did not know how to find "identity" often enough, both with regard to nourishment and to hostile animals [...] had a slighter probability of survival than he who in all cases of similarity immediately guessed that they were identical' (GS 111). Given such passages, it would be very strange to find out that objects such as leaves, twigs, trees, and animals do not exist! For now, then, it will be assumed that eliminativism is not best supported by Nietzsche's texts.

Let me take stock. I have suggested that Nietzsche believes that (CV1) only bundles of forces exist; (CV2) if so, then if objects exist, they are identical to unified bundles of forces; and (CV3) objects exist. CV4 follows: objects are identical to unified bundles of forces.

Constructivism enters the picture with CV5, according to which bundles of forces are unified by virtue of human practices. Nietzsche accepts CV5 when he writes, 'A "thing" is the sum of its effects, synthetically united by a concept' (KSA 13:14[98]). For Nietzsche, the empirical properties of objects appear to be the sensible, macroscopic 'effects' of interactions of bundles of forces at the basic level of reality. ${ }^{9}$ Bundles of forces are unified by virtue of human practices because we employ concepts that organize empirical properties. This is similar to Kant's position that objects are unities derived from conceptually synthesizing the sensory manifold. Whereas Kant argues that objects are structured by an a priori, 
necessary conceptual framework, however, Nietzsche seems to think all concepts are a posteriori and contingent because they are formed exclusively in relation to our needs, interests, and values. Particular groupings of conceptually organized properties then form particular objects. Nietzsche explains that 'A thing = its qualities; but these equal everything which matters to us about that thing; a unity under which we collect the relations that may be of some account to us' (KSA 12:2 [77]). By conceptually unifying sensible properties, bundles of forces are unified by virtue of human practices. This justifies CV5. If CV1-CV5 are true, CV6 follows: objects are identical to bundles of forces unified by virtue of human practices. $^{10}$

What is the import of saying that Nietzsche takes objects to be socially constructed? One might wonder whether lone individuals can create objects, for instance. On Nietzsche's account, this does not appear to be the case. Object construction requires the application of language, specifically conceptual representation, and language is a social phenomenon-there are no solipsistic concept users. For Nietzsche, language is a social phenomenon because representational consciousness itself is a social phenomenon. He claims that representational consciousness arises with the 'ability' and 'need' to 'communicate', such that 'consciousness actually belongs not to man's existence as an individual but rather to the community- and herd-aspects of his nature' (GS 354). ${ }^{11}$ Language and consciousness have a social existence, rather than an individual existence. Object construction is unique to human existence. Many animals are social, of course, but Nietzsche follows Schopenhauer in thinking that only human beings can represent the world conceptually. ${ }^{12}$ Animals have minds, but they are not conscious-they cannot conceptually organize experience. Nietzsche therefore takes construction to be practiced by groups of human beings. ${ }^{13}$

Finally, turn to CV7, which holds that if objects are identical to bundles of forces unified by virtue of human practices, then human practices bring all objects into existence. This premise turns on Nietzsche's view that the existence conditions of objects are determined by the identity conditions of objects. ${ }^{14}$ To say that some object exists is to identify what kind of object it is. To exist is to have some individuating condition of identity. There is no bare existence, but only existence as some kind of thing or other. When Nietzsche writes, 'A thing = its qualities', he equates the existence of an object with what identifies it. ${ }^{15}$ Of course, the phrase that 'A 'thing' is the sum of its effects [viz., empirical properties]' (KSA 13:14[98], emphasis added) suggests that there is something more, namely, something other than empirical properties that provides a ground for such properties. The 'its', however, is misleading - a snare of grammar, Nietzsche would say. There is nothing non-empirical that grounds empirical properties. Objects are identical to identity conditions supplied by organized properties, which are fixed by the application conditions of our concepts. An object is a unity of properties created through the application of concepts. Objects come into existence when we form concepts that collect properties under a general designation. The set of properties over which our concepts generalize determine the identity conditions of objects. 
Consider a toy example to illustrate the basic view. If some object $a$ is a planet while $b$ is not, it is because the application conditions of the concept of being a planet, which we devise, determine the conditions under which entities are identified as planets, such that $a$ but not $b$ has the identity conditions of a planet. Perhaps $a$ but not $b$ has such conditions because, like in the case of Pluto, we decide that $b$ lacks properties that we take to be required for something to be a planet. Planets come into existence by being able to apply the concept of being a planet to some portion of the world. Importantly, Nietzsche sees no ontologically significant difference between objects such as planets and other concrete objects, such as trees, cats, or chairs. Obviously, I cannot defend this extension here. It will suffice to say that his statements that advance constructivism are perfectly generalthey concern all objects we can encounter in experience. If true, CV8 follows: we bring all objects into existence. ${ }^{16}$

\section{Objections to Nietzsche's Object Constructivism}

I now respond to five pressing objections to reading Nietzsche as a constructivist about objects that have not been addressed by commentators defending constructivist interpretations of Nietzsche. The objections primarily concern issues that could be raised from inside Nietzsche's philosophical programspecifically, constructivism appears to be inconsistent with some of his other commitments-but they also concern constructivism in general. My main goal, then, is to show that Nietzsche's constructivism is consistent with his other philosophical views. But I also want to provide some reason to think that his constructivism is not a hopelessly flawed philosophical position in its own right. It will emerge that Nietzsche's constructivism is perfectly compatible with some of his prominent metaphysical commitments and the view stands up against standard objections. ${ }^{17}$

\subsection{Eliminativism in The Gay Science 110}

A challenge to my reconstruction of Nietzsche's argument for constructivism is that Nietzsche embraces the eliminativist view that objects do not exist. The most straightforward evidence for eliminativism occurs in The Gay Science $110 .{ }^{18}$ In that passage, Nietzsche appears to reject CV3, which holds that objects exist. Nietzsche writes:

Through immense periods of time, the intellect produced nothing but errors; some of them turned out to be useful and species-preserving [...] Such erroneous articles of faith, which were passed on by inheritance further and further, and finally almost became part of the basic endowment of the species, are for example: that there are enduring things, that there are identical things; that there are things, kinds of material, bodies; that a thing is what it appears to be (GS 110, italics added). 
Nietzsche says that the view 'that there are things' is an error. The passage by itself provides no justification for this claim, but passages immediately before and after GS 110 suggest that Nietzsche denies the existence of objects because he believes that there is no definite structure to the world. In GS 109, he remarks, 'The total character of the world, by contrast, is for all eternity chaos [...] in the sense of [...] a lack of order' (italics added). GS 111 reports, 'the beings who did not see things exactly had a head start over those who saw everything "in a flux"' (italics added). And in GS 112, Nietzsche writes, 'We have uncovered a diverse succession where the naïve man and investigator of older cultures saw only two different things, "cause" and "effect", as they said; we have perfected the picture of becoming' (italics added). Arguably, for something to be an object, there must be some definite structure to the world. According to the eliminativist, Nietzsche denies that the world has any such structure. ${ }^{19}$ Nietzsche writes that the world is 'chaos', 'flux', or 'becoming', terms which he uses more or less interchangeably. Lack of structure can be attributed to the nature of bundles of forces. For Nietzsche, forces are always in tension, and the eliminativist claims that wholesale tension renders impossible the formation of any definite structure in the world. Thus, Nietzsche notes, 'no things remain but only dynamic quanta, in a relation of tension to all other dynamic quanta' (KSA 13:14[79]). On the eliminativist reading, Nietzsche's ontology is incompatible with the existence of objects. Objects are merely 'erroneous articles of faith'.

The eliminativist reading of GS 110, though, can be contested. First, in The Gay Science, Nietzsche claims that the nature and existence of objects depend on our constructive activities. He introduces this idea in GS 57:

[Y] ou call yourself realists and insinuate that the world really is the way it appears to you: before you alone reality stands unveiled [...] You still carry around the valuations of things that originate in the passions and loves of former centuries! [...] Your love of 'reality', for example-oh, that is an old, ancient 'love'! In every experience, in every sense impression there is a piece of this old love; and some fantasy, some prejudice, some irrationality, some ignorance, some fear, and whatever else, has worked on and contributed to it. That mountain there! That cloud over there! What is 'real' about that? Subtract just once the phantasm and the whole human contribution from it, you sober ones! Yes, if you could do that! If you could forget your background, your past, your nursery school-all of your humanity and animality! There is no 'reality' for us-and not for you either, you sober ones-.

According to Nietzsche, 'realists' who believe they have access to a fully mind-independent world-a world in which 'reality stands unveiled' - are mistaken. We 'carry around the valuations of things [...] of former centuries' in 'every experience', Nietzsche proclaims, such that one cannot 'subtract' the 'human contribution' without denying reality altogether. The nature of reality is therefore conditioned by ways in which our predecessors interpreted and valued the world, and we have inherited these interpretive and valuational judgments.

Nietzsche follows GS 57 by endorsing constructivism. Here is the passage: 
Only as creators!-This has caused me the greatest trouble and still does always cause me the greatest trouble: to realize that what things are called is unspeakably more important than what they are. The reputation, name, and appearance, the worth, the usual measure and weight of a thingoriginally almost always something mistaken and arbitrary, thrown over things like a dress and quite foreign to their nature and even to their skin -has, through the belief in it and its growth from generation to generation, slowly grown onto and into the thing and has become its very body: what started as appearance in the end nearly always becomes essence and effectively acts as its essence. 'What kind of a fool would believe that it is enough to point to this origin and this misty shroud of delusion in order to destroy the world that counts as "real", so-called "reality"!' Only as creators can we destroy!-But let us also not forget that in the long run it is enough to create new names and valuations and appearances of truth in order to create new 'things' (GS 58).

This may strike readers as rejecting constructivism, not endorsing it. Nietzsche appears to distinguish between what an object is called and what an object really is. He indicates that 'what things are called' is distinct from 'what they are'. Names are 'thrown over things like a dress' and therefore 'quite foreign' to an object's 'nature' and 'skin'. Nietzsche seems to think that objects have a nature prior to, and thus independent of, our representational activities.

This reading, however, cannot be correct. Nietzsche proclaims: 'What kind of a fool would believe that it is enough to point to this origin and this misty shroud of delusion in order to destroy the world that counts as "real", so-called "reality"!' It is foolish to believe that we can point to the world prior to our engagement to abolish the real world. The real world is not only conditioned by our interpretations and valuations, as Nietzsche explains in GS 57, but also constructed by our interpretations and valuations, as Nietzsche concludes in GS 58. The interpreted and valued world, according to Nietzsche, is the real world. From 'generation to generation', our interpretations and valuations, which determine the 'reputation, name, and appearance, the worth, the usual measure and weight of a thing', have '[grown] onto and into' objects to become their very 'essence'. It is even 'enough to create new names and valuations', Nietzsche announces, to 'create new "things"'. Hence, human practices can constitute reality, specifically the nature and existence of objects. The idea that our practices construct the world is reiterated later in The Gay Science. Nietzsche writes, 'It is we, the thinking-sensing ones, who really and continually make something that is not yet there: the whole perpetually growing world of valuations, colors, weights, perspectives, scales, affirmations, and negations. This poem the we have invented is constantly internalized, drilled, translated into flesh and reality [...] by the so-called practical human beings (our actors)' (GS 301, last emphasis added). In short: our practical activities play a vital role in constituting reality. And remember the primary point of GS 58, which is that 'Only as creators can we destroy!' This proclamation makes sense only if objects essentially depend on our activities. 
Bringing objects into existence cannot bring others out of existence if objects have a nature that is essentially independent of our practical engagements. There is then good reason to suppose that Nietzsche endorses constructivism in GS 58.

Return now to the issue at hand, namely, whether we should accept an eliminativist reading of GS 110 . On my view, GS 57 and 58 must be taken into consideration when interpreting GS 110. In GS 110, Nietzsche explains that 'since time immemorial' our intellect 'passed on by inheritance' advantageous interpretive judgments that have turned out to be 'errors'. At issue is the error 'that there are things'. Given the information provided in GS 57 and 58, this does not seem to be the error that we interpret objects to exist, but in reality, no objects exist. For Nietzsche, not only is human interpretation a necessary condition of reality, but the nature and existence of objects even depend on our interpretive activities. It seems that Nietzsche must have in mind some other error.

What could it be? Recall he says that it is a mistake to believe 'that there are enduring things; that there are identical things; that there are things, kinds of material, bodies; that a thing is what it appears to be'. The first assertion ('that there are enduring things') names a kind of object. The second assertion ('that there are identical things') names another kind of object. The third assertion ('that there are things, kinds of material, bodies'), I submit, names a further kind of object: objects that are fundamentally material. It is not a coincidence that Nietzsche links objecthood, materiality, and body. After he reports that it is an error to believe 'that there are things, kinds of material, bodies', he adds that it is an error to believe 'that a thing is what it appears to be' (GS 110). On my reading, Nietzsche holds that it is a mistake to assume that the appearance that objects are fundamentally material implies that objects are this way. In the passage immediately preceding GS 110, he asserts that 'matter is as much of an error as the god of the Eleatics' (GS 109). What plays the role of the 'god of the Eleatics', such as Parmenides, is something fundamental. Consequently, the idea that 'matter is as much of an error as the god of the Eleatics' indicates that it is a mistake to think that objects are fundamentally material.

Nietzsche arrives at this conclusion for naturalist reasons. In GS 109, he asks, 'When will we have completely de-deified nature? When may we begin to naturalize humanity with a pure, newly discovered, newly redeemed nature?' Nietzsche takes modern science to show that at the fundamental level, reality consists in forces, not material bodies. This shows the influence of mathematician and physicist Roger Boscovich. In a letter written in March 1882, when Nietzsche was preparing The Gay Science to be published later that year, he claims that 'With effect from [Roger Boscovich] there is no 'matter' any more-except as a source of popular relief. [Boscovich] has thought the atomistic doctrine through to the end ${ }^{\prime 20}$ Trust in Boscovich provides Nietzsche with a naturalist motivation to reject fundamentally material objects. ${ }^{21}$

Boscovich, who anticipates developments in modern point particle physics, contends that non-extended physical force points are the ultimate constituents of matter. The relative positions and velocities of force points, Boscovich claims, 
together with a complex law of force, can account for all properties of matter. He remarks, 'it will be found that everything depends on the composition of the forces with which these particles of matter act upon one another: and from these forces, as a matter of fact, all phenomena of Nature take their origin' (Boscovich 1922: 6). Boscovich contends that within Newtonian physics contact between two extended spheres moving at different velocities is impossible without breaking the law of continuity. The law of continuity holds that changes in velocity happen continuously. To avoid interpenetration, contact between the spheres would require velocities to change both instantaneously and discontinuously, which is impossible. Boscovich hypothesizes that changes in velocity between spheres are due to repulsive forces acting at small distances between the spheres. This requires force points to be fundamental. ${ }^{22}$

In later work, Nietzsche explicitly endorses Boscovich's view of fundamental reality (see BGE 12, cf. 36), and Nietzsche's praise for Boscovich when writing The Gay Science explains why he asserts that the world is 'chaos', 'flux', or 'becoming'. Boscovich helps provide Nietzsche with a 'newly discovered, newly redeemed nature' (GS 109). Nietzsche's naturalist preference for contemporary scientific reasoning leads him to believe that objects are not ultimately material. The error 'that there are things, kinds of material, bodies' is not that the error that we fail to understand that objects do not exist. The error is that, despite appearances, we fail to understand what modern science delivers, which is that no fundamentally material objects exist. Moreover, despite the fact that we think the world is comprised of fundamentally material objects, we cannot bring such objects into existence. Boscovich has shown this to be impossible. Naturalism constrains what can be constructed. An eliminativist reading of GS 110 is therefore implausible: Nietzsche denies the existence of a certain kind of object, but not objects altogether. For Nietzsche, the world exists in a state of 'chaos', 'flux', or 'becoming', and objects are constructed within such a world.

\subsection{Anthropomorphism}

Another objection to reading Nietzsche as a constructivist is that construction involves interpreting the world to have human features, but Nietzsche is critical of such anthropomorphism (see, e.g., GS 109; BGE 22). Now, constructivist readers might reject this charge at the outset. Constructivism does not hold that objects have human qualities, but that the properties objects have results from human action. The phenomenalist view that the properties of objects are identical to our perceptual states appears to be anthropomorphic. ${ }^{23}$ But constructivism is not phenomenalism. Nonetheless, it might be argued that for Nietzsche, what objects are rests on features of what subjects are. This could motivate the charge of anthropomorphism. Consider the following:

Man's three 'inner facts', the things he believed most firmly-the will, the mind, the I-were projected out of himself: he derived the concept of Being 
from the concept of the I, and posited the existence of 'things' after his own image, after his concept of the I as cause [...] The thing itself, to say it again, the concept of thing: just a reflection of the belief in the I as cause (TI 'Errors' 3; see also 'Reason' 5; GM I: 13; KSA 12:2[83]).

The idea is that agents fashion and apply the concepts of Being and objecthood based on the belief that the self is an entity ontologically independent of its will. Since Nietzsche holds that belief in this conception of the self is erroneous, it seems to follow that belief in Being and objects is erroneous. It appears that organizing the world into objects rests on an anthropomorphic error.

Consider Being before turning to objects. In general, Nietzsche understands Being in a Parmenidean sense: Being is that which is distinct from change but renders change possible. ${ }^{24}$ According to Nietzsche, people believe the world exhibits Being because, insofar as 'every event [is] an action, every action the result of a will', they consider the subject to be ontologically distinct from its willed actions, and project this belief 'onto every event' (TI 'Errors' 3). As a result, 'Being is thought in, foisted in everywhere as cause; only following on from the conception "I" is the concept "Being" derived' (TI 'Reason' 5). On Nietzsche's account, there is no ontologically distinct self, or 'substratum', apart from a subject's actions. He writes, "There is no "being" behind doing, effecting, becoming; "the doer" is merely a fiction added to the deed-the deed is everything' (GM I: 13). Subjects are not ontologically independent of their actions. In a similar manner, reality is wholly dynamic. Hence, it is incorrect to believe that the world exhibits Being.

Now consider objects. For Nietzsche, belief in the subject-action conception of the subject lures philosophers into thinking that objects have natures ontologically independent of changes they might undergo. This form of anthropomorphism leads to a view of objecthood that assumes intrinsic properties constitute an object's identity. Here, $F$ is an intrinsic property of any object $a$ if and only if $a^{\prime}$ s having (or not having) $F$ is ontologically independent of the existence, and of the non-existence, of any contingent $b$ such that $a$ is wholly distinct from $b$. Importantly, Nietzsche can criticize the idea that objects have intrinsic properties while embracing constructivism. Constructivism holds that all properties of objects are ontologically dependent on human practices. Thus, constructivism denies that intrinsic features constitute the conditions of identity of objects. Nietzsche's criticism of anthropomorphism about objects is therefore consistent with his constructivism.

What should we make of Nietzsche's attacks on anthropomorphism? Consider the most recognized passage on the topic:

Let us beware.-Let us beware of thinking that the world is a living being. [...] After all, we know roughly what the organic is; are we then supposed to reinterpret what is inexpressibly derivative, late, rare, accidental, which we perceive only on the crust of the earth, as something essential, common, and eternal, as those people do who call the universe an organism? Let us beware even of believing that the universe is a machine 
[...] The total character of the world, by contrast, is for all eternity chaos, not in the sense of a lack of necessity but a lack of order, organization, form, beauty, wisdom, and whatever else our aesthetic anthropomorphisms are called [...] Let us beware of attributing to it heartlessness or unreason or their opposites: it is neither perfect, nor noble, nor beautiful, nor does it want to become any of these things; in no way does it strive to imitate man! In no way do our aesthetic and moral judgments apply to it! [...] Let us beware of saying that there are laws in nature. There are only necessities: there is no one who commands, no one who obeys, no one who transgresses [...] Let us beware of thinking that the world eternally creates new things. There are no eternally enduring substances; matter is as much of an error as the god of the Eleatics. But when will we be done with our caution and care? When will all these shadows of god no longer darken us? When will we have completely de-deified nature? When may we begin to naturalize humanity with a pure, newly discovered, newly redeemed nature? (GS 109).

The end of the passage reveals Nietzsche's target: 'shadows of God'. This is telling. As Cristoph Cox writes, Nietzsche 'calls for a "de-deification", rather than a "dehumanization", of nature' (1999: 102). Rather than saying human practices must be washed out of our interpretations of the world, Nietzsche thinks that our interpretations of the world should be naturalized. Commitment to naturalism informs Nietzsche's conviction that the world should not be interpreted to have features often believed to have been granted by God, such as eternal form, purpose, order, beauty, laws of nature, substance, and so on. ${ }^{25}$ This is not an objection to anthropocentric interpretation tout court, but rather to anthropomorphic interpretation inconsistent with naturalism. ${ }^{26}$

Constructivism is perfectly compatible with naturalism. ${ }^{27}$ It even appears that on Nietzsche's account, all organic phenomena are engaged in rudimentary 'constructive' activity. He notes, 'As a matter of fact, the existing world, which is relevant for us, is made by us-by us, that is, by all organic beings-it is the product of the organic process' (KGW VII/2, 26[203]), and 'men and all organic creatures have done more or less the same thing: they have arranged, thought, devised the world to fit, until they could make use of it, until it could be "reckoned" with" (KSA 11:40[36]). Organic beings function successfully by engaging in activities that contribute to structuring the world in accordance with their purposes. The activity of constructing objects on the part of human beings is just a highly complex instance of the organizational process in which all natural beings participate. ${ }^{28}$ Nietzsche's constructivism and his naturalism therefore fit nicely with one another.

A last criticism of anthropomorphism requires attention. Nietzsche often attacks the Protagorean idea that human beings are 'the measure of all things'. These criticisms, I suggest, are compatible with Nietzsche's constructivism. Consider four representative passages. In 'On Truth and Lies in a Non-moral Sense', Nietzsche denies that we can 'treat man as the measure of all things' (TL 1). 
However, he justifies this claim by arguing that we cannot know the basic nature of the objects of experience. Beginning with Human, All Too Human, he is increasingly skeptical of such a position, until eventually he comes fully to reject the notion. It becomes clear that Nietzsche takes objects to be perfectly knowable. The position on objects in 'On Truth and Lies in a Non-moral Sense' does not represent his mature philosophical position.

Other passages that address the Protagorean view do not target constructivism. In Human, All Too Human, Nietzsche denies that 'man' is a 'sure measure of things' because we cannot draw conclusions about the nature of all humankind from the nature of contemporary humankind (HH I: 2). This holds regardless of the truth or falsity of constructivism. In Beyond Good and Evil, Nietzsche rejects the assumption that "not just man is the "measure of things"' because he rejects the view that we must appeal to some standard fully outside human experience to judge our practices (BGE 3). ${ }^{29}$ Again, constructivism is not at issue. And finally, although Nietzsche does say in his notebooks that the 'hyperbolic naiveté of man' is 'positing himself as the meaning and measure of the value of things', he adds that this naiveté occurs because 'the values by means of which we have tried to render the world estimable for ourselves and which proved inapplicable and therefore devaluated the world [...] have been falsely projected into the essence of things' (KSA 13:11[99]). We have fashioned values that cannot be realized in the conditions of this world, but our false sense of confidence renders us unaware of this fact. Constructivism is an altogether different matter. Nietzsche's Protagorean criticisms then do not impede his approval of constructivism about objects.

\subsection{Contradiction}

A third objection to constructivist interpretations can be extracted from a passage in Daybreak. Nietzsche writes:

Words lie in our way!-Wherever primitive mankind set up a word, they believed they had made a discovery. How different the truth is!-they had touched on a problem, and by supposing they had solved it they had created a hindrance to its solution.-Now with every piece of knowledge one has to stumble over dead, petrified words, and one will sooner break a leg than a word (D 47, cf. KSA 11:34[195]).

Here is why the passage possesses a problem for reading Nietzsche as a constructivist. The constructivist holds that by devising and applying concepts to the world in experience, we bring objects into existence. When our ancestors devised and applied concepts to the world, then, it is reasonable to think they brought certain objects into existence. But according to the passage above, Nietzsche thinks that their efforts failed to represent reality. So, the objection goes, it appears that our ancestors brought into existence objects that do not exist! Examining constructed objects at a particular time, rather than over time, could generate a similar problem. If constructivism were true, it seems that one group 
of people could state that some object exists, while another group could state that the same object does not exist-and both could be right. Since this possibility results in a contradiction, constructivism is false. Here is the argument:

(CO1) If constructivism is true, then it is possible that some object $O$ exists and does not exist.

(CO2) It is not possible that $O$ exists and does not exist.

(CO3) So, constructivism is false.

In order to understand Nietzsche's response, consider objects such as planets. The non-constructivist holds that if planets are constructed then it is possible that they both exist and do not exist. Perhaps, one group of astronomers $A_{1}$ adopts our current view and maintains that planets are objects that orbit our Sun, retain hydrostatic equilibrium, and have 'cleared the neighborhood' around their orbit. Can another group of astronomers $\mathrm{A}_{2}$ produce an inconsistent description? It is easy to imagine $\mathrm{A}_{2}$ stating that planets exist but with different identity conditions. But this would not conflict with statements made by $\mathrm{A}_{1}$. Obviously, it is possible to state that planets both exist and do not exist if there are differently specified sets of what constitutes the application conditions of the concept of being a planet. Perhaps, only one set is correct. Additionally, if it is specified that planets are objects with a particular set of identity conditions-that either $A_{1}$ or $A_{2}$ is correct -it is not possible to state correctly that planets both exist and do not exist. If there are objects with those identity conditions, planets exist, and if not, planets do not exist. So, CO1 is false. Constructivism can be true and not result in one and the same object both existing and not existing.

How does Nietzsche understand the constructive practices of different groups of people, particularly our ancestors? Nietzsche thinks that there are constraints on object construction. Most importantly, sensory information must be accounted for when organizing the world in some way rather than another. If no attention is paid to sensory information, then objects cannot be brought into existence. Sensory information brings agents into contact with empirical properties, and concrete objects are organized units of such properties. Yet sensory information does not by itself constrain organization in any unique manner. Information relevant to our purposes draws greater attention. "We construe "what is" as what exerts an effect on $u s^{\prime}$, Nietzsche says, and what is "really, truly there" is one we drew out of the "mattering-to-us"' (KSA 12:5[19]). ${ }^{30}$ Our ancestors constructed objects in accordance with how they were affected in accordance with their interests. Over time, the ways in which people are affected and what people find relevant change. For Nietzsche, many older ways of organizing the world fail to do justice to the current ways in which we are affected and fail to satisfy current interests. Although our ancestors oftentimes 'believed they had made a discovery', they had only 'touched on a problem' that modern ways of arranging reality are better at addressing (D 47). We have outlived the usefulness of some of the concepts our ancestors applied to describe reality. For this reason, Nietzsche often claims that we need new concepts to better reflect our experiences (see KSA 11:34[195], cf. BGE 211). Due to a difference in our interests and how we attend to experience, 
then, currently constructed objects are either (i) distinct in kind from formerly constructed objects or (ii) the same in kind with distinct identity conditions.

It could also be the case that the objects our ancestors seemed to have constructed never existed. Their organization of reality may simply have been mistaken. Nietzsche writes, "all the concepts of ancient man were rather at first incredibly uncouth, coarse, external, narrow, straightforward, and altogether unsymbolical in meaning to a degree that we can scarcely conceive" (GM I: 6). Our ancestors may have failed to account for certain constraints, such as sensory information. The idea that people have failed to take into consideration crucial constraints on inquiry, particularly constraints provided by naturalism, informs much of Nietzsche's philosophy. In the first essay of On the Genealogy of Morality, for example, Nietzsche contends that the received view of the origin of our moral values, according to which our values are derived from utilitarian and Darwinian presuppositions, fails to reflect reality. The received view ignores reasons that suggest our moral values arose in accordance with various life-negating functions. Although we have overwhelmingly accepted such a view, Nietzsche believes, we are wrong. Something similar could be the case with respect to objects. Our ancestors could have failed to account for constraints that we now know should inform our organization of reality.

\subsection{Unperceived Objects}

Constructivism about objects has perhaps been attacked most often because it cannot account for the nature of unperceived objects. ${ }^{31}$ Since it would seem that unperceived objects are unconstructed, and constructivism holds that all objects are constructed, constructivism appears false. There are three versions of this objection. Constructivism cannot account for objects that currently exist but are unperceived, objects that currently exist but will never be perceived, and objects that existed before there were perceivers. This section concerns how Nietzsche might respond to these objections.

The responses developed below are influenced by themes in Kant. Kantian constructivism had a strong presence in Nietzsche's historical context. Nietzsche was primarily exposed to Kant through Arthur Schopenhauer, Kuno Fischer's commentary on Kant, and the neo-Kantian philosophers Friedrich Albert Lange, Friedrich Überweg, Otto Leibmann, Hermann von Helmholtz, Heinrich Romundt, Afrikan Spir, and Eduard von Hartmann. Kant and the neo-Kantians propose various forms of the position that our cognitive apparatus is an essential condition for there being objects, such that there is no way to cognize objects as they are fully independent of our particular mode of cognition. It is not always clear which Kantian commitments Nietzsche accepts and which he rejects, ${ }^{32}$ but Nietzsche does support Kant's view that the existence of all objects we can experience depends on contributions from the subject, despite the fact that he rejects Kant's a priori metaphysical program. Nietzsche's support of Kant's view of objects, I suggest, reflects his commitment to Kant's conception of empirical reality. And Nietzsche can respond to the objections from unperceived objects by appealing to Kant's conception of empirical reality. ${ }^{33}$ 
The first of these objections turns on the idea that some objects are currently unperceived. Currently unperceived objects are objects existing in the present that have not been encountered, such as distant stars. The existence of such objects suggests this argument:

(UA1) Some objects that currently exist are unperceived.

(UA2) Currently unperceived objects are unconstructed.

(UA3) If UA1 and UA2, then constructivism is false.

(UA4) So, constructivism is false.

UA1 seems clearly true. UA2 appears to be a consequence of Nietzsche's constructivism. Constructivism holds that the nature of all objects depends on us. Since currently unperceived objects seem to have a nature apart from us, currently unperceived objects appear unconstructed. As a result, constructivism appears false.

R. Kevin Hill maintains that Nietzsche has a non-constructivist response to the worry (2003: 138-140). Hill's view turns on a Berkeleyan version of Kantian idealism. For Hill, Nietzsche denies that currently unperceived objects exist-he rejects UA1. On Hill's reading, Nietzsche embraces the panpsychist view that 'there are enough finite minds in existence to guarantee that nothing we want to posit in our empirical theories goes unobserved' (2003: 138). Reality consists in minded forces. Since 'force possesses rudimentary awareness of its milieu', the 'problem of unobserved items is solved' (2003: 138). This settles the worry of currently unperceived objects without committing Nietzsche to constructivism. Hill's reading faces a problem, however, which does not depend on whether or not Nietzsche embraces panpsychism. To my knowledge, no passage in Nietzsche's texts advance the view that reality is constituted by what minded forces 'perceive'. It is therefore implausible that panpsychism provides Nietzsche's answer to the worry about unperceived objects. Nietzsche solves the worry by appeal to a particular kind of perception, I argue, but not the 'perception' of minded forces.

On my account, there is good evidence for thinking that Nietzsche has a Kantian constructivist solution to the problem of currently unperceived objects. Consider Kant before turning to Nietzsche. In the Antinomies of the first Critique, Kant writes:

That there could be inhabitants of the moon, even though no human being has ever perceived them, must of course be admitted; but this means only that in the possible progress of experience we could encounter them; for everything is actual that stands in one context with a perception in accordance with the laws of the empirical progression. Thus they are real when they stand in an empirical connection with my real consciousness, although they are not therefore real in themselves, i.e., outside this progress of experience (1998: A493/B521).

Assume that there are currently unperceived inhabitants on the moon. For Kant, we can represent these inhabitants by encountering them in the advance of experience, specifically by progressing through a series of possible perceptions, 
which is enabled by spatial repositioning. The possible 'progress of experience' links currently unperceived objects with a 'real consciousness'. What is 'actual', or empirically real, is what can be encountered in the 'context' of possible perception. For Kant, 'appearances [viz., empirical objects] [...] are real only in perception' and 'nothing is really given to us except perception and the empirical progress from this perception to other possible perceptions' (1998: A493/B521, my brackets). This means that 'to call an appearance a real thing prior to perception means either that in the continuation of experience we must encounter such a perception, or it has no meaning at all' (1998: A493/B521). If we cannot in principle perceive something, then it has no reality, and therefore, we cannot say anything meaningful about it.

Nietzsche endorses Kant's view of empirical reality. He asserts 'We construe "what is" as what exerts an effect on us, what proves itself by exerting its effect.-“Unreal", "illusory", would be that which is incapable of producing effects' (KSA 12:5[19]). Empirical reality is that which can affect us in experience. For Nietzsche, 'Things are only the boundaries of man' (D 48). Nietzsche's Kantian conception of reality indicates that currently unperceived are constructed-that UA2 is false. Constructivism holds that all objects we can encounter in experience are constructed. If a currently unperceived object is perceivable, then its identity conditions depend upon our representational activities. Of course, it is meaningless to describe currently unperceived objects beyond expressing the empty idea that something may be currently unperceived. But Nietzsche takes the nature of currently unperceived objects to be determined in relation to how they would be described should they be encountered.

Next, consider objects that will never be perceived. The existence of such objects suggests this argument against constructivism:

(UB1) Some objects that currently exist will never be perceived.

(UB2) Objects that will never be perceived are unconstructed.

(UB3) If UB1 and UB2, then constructivism is false.

(UB4) So, constructivism is false.

Objects that currently exist but will never be perceived can be understood in two ways. Perhaps, some objects will never be perceived because, although they are perceivable, they will never be encountered. On this reading, Nietzsche will deny UB2. Like Kant, he believes that perceivable objects are constructed. But, perhaps, some objects will never be perceived because they are strictly unperceivable. It is clear that such objects are unconstructed. If this reading were adopted, Nietzsche would reject UB1. According to Nietzsche, unperceivable objects do not, in fact, exist.

Unperceivable objects are objects in principle inaccessible to our mode of cognition. For Nietzsche, such objects are what Kant calls 'things in themselves'. Kant maintains that something in itself is not a possible object of experience, but the condition of there being possible objects of experience. Since the objects of possible experience are those we can conceptually represent, something in itself 
cannot be represented by using concepts. And because Kant takes conceptual representation to determine the limits of our cognition, something in itself is inaccessible by our mode of cognition. So, things in themselves cannot be cognized. Kant nonetheless claims that 'we at least must be able to think them as things in themselves' (1998: Bxxvi-xxvii). We must be able to think about things in themselves as a condition of the existence of appearances. 'For otherwise there would follow the absurd proposition that there is appearance without anything that appears' (1998: Bxxvi-xxvii). The absurdity is to think that appearance-the world comprised of cognizable objects-can exist without conditions that allow appearance. According to Kant, this justifies postulating things in themselves.

Nietzsche's argument against things in themselves, and thus UB1, unfolds as follows. Nietzsche asserts, 'There are no things in themselves! [...] Something that is of no concern to anyone is not at all' (KSA 12:2[154]). Readers might find this puzzling: why think objects do not exist just because no one has epistemic access to them $?^{34}$ It has been established that things in themselves are in principle inaccessible to our mode of cognition. A thing in itself, then, is best understood as a conceptual placeholder that stands for an object that exists independently of our cognitive capacities. If this is the case, things in themselves either cannot be coherently conceived or cannot be conceived without contradiction. Nietzsche maintains that we can have either no coherent conception of an object we cannot in principle cognize, or we can only have a contradictory conception of an object we cannot in principle cognize (see GM III: 12; BGE 16; GS 54). If something cannot be coherently conceived, or cannot be conceived without contradiction, Nietzsche suggests, it does not exist. This links something's being conceivable to something's existing. The implication is certainly not true across all cases. But it does seem warranted in the case of unperceivable objects. The inability to entertain a coherent concept of an object that can only be understood as a concept indicates that the object does not exist. Or, the inability to entertain a concept of an object that can only be understood as a concept without contradiction indicates that the object does not exist. Consequently, things in themselves do not exist. As Nietzsche remarks, the world of things in themselves is a 'purely fictitious world' (KSA 13:11[99]). ${ }^{35}$

Turn finally the last of the three objections from unperceived objects: objects in the past. Constructivism appears false because there were objects far before there were perceivers. Here is the argument against Nietzsche:

(UC1) Some objects exist before perceivers.

(UC2) Objects that exist before perceivers are unconstructed.

(UC3) If UC1 and UC2, then constructivism is false.

(UC4) So, constructivism is false.

Objects that exist before perceivers are either perceivable or not perceivable. If they are not perceivable, Nietzsche will reject their existence. That is, he will deny UC1 by claiming objects that exist before perceivers must be perceivable. If they are 
perceivable, then they are constructed. But this runs directly into a problem: how do we perceive and construct objects before we exist?

Again, Nietzsche can follow Kant's lead. In the Antinomies, Kant says ${ }^{36}$ :

All those events which have elapsed in the immense periods that have preceded my own existence mean really nothing but the possibility of extending the chain of experience from the present perception back to the conditions which determine it in time (1998: A495/B523, translation slightly modified).

Past phenomena are identified with the possibility of extending perceptions of something in the present back to that which determines the present perception as arising in the course of time. A necessary condition of determining a present perception as arising in the course of time seems to be that a presently perceived object must be perceived as having some past. I perceive my dog now, for instance, one day from when I last perceived him. The present perception of my dog is the latest in the chain of ongoing possible perceptions of my dog that precede the present. If my aim is to represent 'immense periods that have preceded my own existence', however, then I must represent something that has some permanent reality, which Kant regards as substance. He writes, 'That which persists, in relation to which alone all temporal relations of appearances [viz., objects] can be determined, is substance in the appearance, i.e. the real in the appearance, which as the substratum of change always remains the same' (1998: B225, my brackets). Since objects with a substantial basis endure, it is possible to represent reality before perceivers. Importantly, Kant maintains that the existence conditions of past objects depend solely upon our ability to represent those objects. The past is 'nothing but the possibility of extending the chain of experience', he claims, and 'objects' are 'real in past time only insofar as I represent to myself' a 'regressive series of possible perceptions' that 'leads to a time-series that has elapsed as the condition of the present time' (1998: A495/B523, italics added). The existence conditions of past objects depend essentially on presenting to myself a set of possible experiences that can be traced back which determine my current perceptions.

Nietzsche can follow Kant, but only to a certain extent. Nietzsche famously rejects conceiving objects as substances. He must then give an account of how we can represent past objects without appeal to some permanent reality. For this task, he could appeal to Kant's insight that the existence conditions of past objects depend on representing presently perceived objects as having a history that can be tracked. In order to attend to present perceptions in this manner, it is not required that we represent substantial objects that abide the permanent flow of time. Rather, we could attend to present perceptions by attending to a chain of causes and effects that stretch into the past. Kant even mentions that the past exists in 'the footsteps of causes and effects' (1998: A495/B523).

For Nietzsche, past objects are perceivable and constructed in the following way. Objects come into existence at some time and cease to exist at another. This 
process is causally conditioned. Since the conditions of the present are a causal consequence of the conditions of the past, the existence conditions of past objects depend essentially on the possibility that we can track causal interactions from the present back in time. More specifically, the existence conditions of some object $\mathrm{O}$ depend essentially on the possibility that we can track a series of causal interactions back from some present perception to a context in which the application conditions for the category of $\mathrm{O}$ are met. The identity conditions of $\mathrm{O}$ are constructed, then, because the application conditions of our concepts involve conditions relevant to us about whether some concept correctly applies to some portion of experience. To illustrate, if something is identified as some kind of object before there were perceivers, say dinosaur D, it is because we can track a successive causal chain back from some present perception, perhaps the perception of some configuration of fossils, to a context in which the application conditions for the category D are satisfied, and we decide that some set of conditions, rather some other, correctly constitute that context. Since applications conditions fix conditions of identity for whatever satisfies them, Nietzsche can say that perceivable objects before perceivers are constructed.

Of course, Nietzsche's Kantian account has limitations. In particular, it cannot make sense of past objects that have no causal connection to what can be presently perceived. But this limitation is not unique. It is shared by any account of historical phenomena. And it is important to remember that Nietzsche's view does not require actually tracking causal interactions back in time from present perceptions, but only the possibility of such tracking procedures. Kantian constructivists like Nietzsche think that the identity conditions of objects depend essentially on the possibility of being represented and only reject the view that objects have conditions of identity regardless of such possibility.

I have argued that key themes in Kant's first Critique can help Nietzsche respond to three variants of the charge that constructivism about objects cannot account for unperceived objects. Currently unperceived objects, as well as objects before perceivers, are constructed if they are perceivable, and strictly unperceivable objects do not exist. Nietzsche can therefore respond to the charge most often thought to undermine constructivism.

\subsection{Circularity}

On Nietzsche's account, objecthood appears to be a relational property, namely, being an object in relation to our activities. ${ }^{37}$ This view has been charged with being problematically circular. ${ }^{38}$ Nietzsche seems to employ the notion of subjects to explain construction, but subjects could themselves be considered objects too. This generates the following argument against constructivism:

(CC1) Subjects are objects.

(CC2) So, if constructivism is true, then the identity conditions of subjects depend essentially on subjects' interpretive practices. 
(CC3) The identity conditions of subjects do not depend essentially on subjects' interpretive practices.

(CC4) So, constructivism is false.

CC1 is justified on the idea that subjects are a particular type of object, namely, living human objects. CC2 is warranted by substituting 'subject' for 'object' in the constructivist thesis. The worry about circularity applied to subjects justifies CC3. Assuming that existence conditions require conditions of identity, to deny CC3 would be to say that the existence of subjects is dependent on subjects interpreting themselves to exist. But, surely, the existence of subjects interpreting themselves to exist is dependent on subjects existing. Thus, when constructivism is applied to subjects as objects, constructivism is false.

Nietzsche's response depends on fleshing out his conception of the subject. He certainly rejects the view that subjects are substances. He often describes the substance view of the subject as the position that "II" is the condition, "think" is the predicate and conditioned-thinking is an activity to which thought must supply a subject as cause' (BGE 54). The view that "There is thinking: therefore there is something that thinks" [...] means positing as "true a priori" our belief in the concept of substance' (KSA 12:10[158]). Against the tradition which has adopted the substance view of the subject, Nietzsche comments 'One tried with admirable perseverance and cunning to get out of this net-and asked whether the opposite might not be the case: "think" the condition, "I" the conditioned; " $\mathrm{I}$ " in that case only a synthesis which is made by thinking' (BGE 54). The position that the ' $\mathrm{I}$ ' is a 'synthesis which is made by thinking' is part of Nietzsche's positive view of the subject: 'What separates me most deeply from the metaphysicians is: I don't concede that the " $\mathrm{I}$ " is what thinks. Instead, I take the I itself to be a construction of thinking' (KSA 11:35[35]). The substantial ' $\mathrm{I}$ ' does not exist, while the ' $\mathrm{I}$ ' that exists is a 'construction'. This suggests that the subject is real, but constructed.

Nietzsche famously regards the human subject as a multiplicity, or a 'social structure of the drives and affects' (BGE 12). Being a genuine subject depends on constructing a functionally coordinated hierarchy of drives and affects. Drives and affects produce inclinations and aversions that determine thought and behavior. For Nietzsche most human beings are nothing more than a diversity of competing tendencies. Most, then, exist only as mere parts of selves: 'When my eyes flee from the now to the past they always find the same: fragments and limbs and dreadful accidents-but no men' (Z II: 'Redemption', see also KSA 12:2[491]). 'One should not at all assume that many humans are "people", Nietzsche says, 'the "person" is a relatively isolated fact' (KSA 12: 10[59]). To be a genuine subject, or 'person', our natural tendencies, which often compel behavior in conflicting manners, must form a coherent organization. Human beings must 'create and carry together into One what is fragment and riddle and dreadful accident' ( $Z$ II: 'Redemption'). Forming a coherent organization places us beyond being a mere human organism, and results in the achievement of a genuine self. 
By disambiguating two meanings of 'subject', Nietzsche might therefore deny CC3, the claim that the identity conditions of subjects do not depend essentially on subjects' interpretive practices. Though the identity conditions of genuine subjects do not depend essentially on genuine subjects' interpretive practices, the identity conditions of genuine subjects depend essentially on the interpretive practices of human organisms. The obvious objection, however, is that while genuine subjects might be constructed, the identity conditions of subjects conceived as human organisms do not depend essentially on the practices of human organisms. The circularity objection could simply be re-stated at the level of the human organism. Human organisms appear to be objects.

Nietzsche has two options here. The first option is to resist CC1. If that premise were reformulated with 'human organism' rather than 'subject', CC1 would claim that human organisms are objects. Does Nietzsche accept this reformulation? He certainly thinks that human organisms, along with objects such as trees and birds, are complex configurations of bundles of forces. However, he also seems to think that there is an ontologically significant difference between human beings and other objects: humans are conscious. ${ }^{39}$ For Nietzsche, recall, consciousness requires a conceptual vocabulary, which only human beings enjoy. 'Conscious thinking takes place in words' (GS 354). Having a conceptual vocabulary can deepen self-awareness, and thus enable human beings to create genuine selves: 'The sign-inventing person is also the one who becomes ever more acutely conscious of himself; for only as a social animal did man learn to become conscious of himself' (GS 354). The idea that human organisms are a unique kind indicates that humans are not objects-or at least not merely objects. If so, then CC1 seems false: subjects are not objects. ${ }^{40}$

Unfortunately, this response faces trouble. Nietzsche needs to provide an account of why having the unique property of consciousness is ontologically different from some kind of object's having some other unique property, such that the former differentiates human existence from the existence of mere objects. Nietzsche gives no such account, however, and it seems perfectly reasonable to suppose that human organisms remain objects despite being conscious. As a result, this challenge to CC1 is weak.

Perhaps, Nietzsche might resist the reformulation of CC3, which holds that the identity conditions of human organisms do not depend essentially on human organisms' interpretive practices. It could be the case that the conditions of identity of the human organism actually depend essentially on the practices of the human organism. Nietzsche appears sympathetic to the idea that the conditions of the human organism that identify it as such are essentially determined by how we understand the human organism. He writes that in man creature and creator are united: in man there is material, fragment, excess, clay, dirt, nonsense, chaos; but in man there is also creator, form-giver, hammer hardness, spectator divinity, and seventh day' (BGE 225). The existence of human organisms need not depend on human organisms interpreting themselves to exist. Rather, having identity conditions might only depend on something existing, specifically something with the ability to interpret, and the identity conditions 
of human organisms are gained when the ability to interpret becomes reflexive. Whatever constructs objects gains its conditions of identity through experiencing itself and the world. On this account, there is no circularity. The ability to construct objects does not imply the existence of an object with predetermined identity conditions. Thus, Nietzsche can deny CC3 by claiming that the identity conditions of subjects do depend essentially on subjects' interpretive activities. This supports his view that the identity conditions of human organisms are not fixed: since 'man has become', he says, 'there are no eternal facts, just as there are no absolute truths' about human beings (HH I: 2).

\section{Summary}

In this paper, I have developed a new argument for interpreting Nietzsche as a constructivist and responded to outstanding objections to Nietzsche's constructivism. Let me review those responses. The first objection was that Nietzsche embraces eliminativism over constructivism. I suggested that a primary passage that appears to advance eliminativism does not do so. Nietzsche rejects fundamentally material objects, not objects in general. The second objection was that Nietzsche's constructivism involves anthropomorphism. I argued that Nietzsche both embraces constructivism and criticizes anthropomorphic interpretations. Such interpretations either erroneously assume that objects have intrinsic properties or fail to meet naturalistic constraints on inquiry, neither of which are plausible interpretations of Nietzsche. The third objection was that constructivism leads to the possibility that some objects both exist and do not exist. In seemingly contradictory cases, however, either different objects are constructed or the contradiction does not arise when an object's identity conditions are specified. The fourth objection was that unperceived objects are unconstructed. If an unperceived object is perceivable, whether in the present or in the past, Nietzsche thinks that it is constructed, and unperceived objects do not exist. The fifth and last objection was that constructivism involves vicious circularity. Nietzsche can deny the circularity by saying either that subjects are distinct from objects or that whatever constructs objects gains conditions of identity through experience of itself and the world. These objections are of course not exhaustive, but I hope to have shown that Nietzsche's constructivism is consistent with some of his other major philosophical commitments, and that no obvious or standard objection undermines his view, despite the fact that his position is certainly far from ordinary.

Justin Remhof

Old Dominion University

USA

jremhof@odu.edu 


\section{ENDNOTES}

1 For prominent non-constructivist readings, see Clark (1990), Leiter (1994), Hales and Welshon (2000), Doyle (2009), and Nola (1987, 1999). For challenges to these readings, see Remhof (2015a), (2017).

2 Nietzsche uses concept [Begriff], word [Wort], and name [Name] more or less interchangeably.

3 'All objects' is shorthand for 'all objects that can be in principle encountered in experience'. See Section 2.4.

4 Other constructivist readers embrace the conclusion of the argument, but none offer detailed enough accounts to assess whether they would embrace all the premises. I argue that all the premises are supported by Nietzsche's texts.

5 See Richardson (1996), Poellner (1995), Schacht (2000), Hales and Welshon (2000), Hill (2007), Doyle (2009), Addis (2013), Emden (2014), Welshon (2014), Loeb (2015), and Strawson (2015).

6 For those who deny that Nietzsche embraces the will to power ontology, see Clark (1990), Leiter (2002), and Clark and Dudrick (2012).

7 See, e.g., GS 349, cf. 118; BGE 13, 19, 22, 23, 47, 51, 230, 259; GM I: 13; A 6, cf. 2, 7, 17; Z II: 'On Self-Overcoming'; KSA 13:14[184], 13:14[93], 11:36[31], 13:14[79], 12:7[9], 13:14[81], 13:14[82], 11:38[12].

8 See Danto (1965), Young (1992), Nola (1987, 1999), Conard (2001), Stack (2005), and Braver (2007).

9 See KSA 12:2[85], 13:14[184], 13:14[93], 12:14[79]. Nietzsche's view of properties reflects the influence of Boscovich. See Section 2.1 for discussion. Since Nietzsche thinks that objects are understood by virtue of their sensible, or empirical, properties, I will not be concerned with properties of space and time. Nietzsche does not seem to think that space and time supply the identity conditions of objects.

10 For the opposing idea that objects are intrinsically unified bundles of forces, which would render CV5 false, see Hales and Welshon (2000) and Doyle (2009). For criticism, see Remhof (2015a), (2017).

11 One might think Nietzsche's constructivism has strange consequences for subjects who are incapable of conceptual thought. Constructivism would imply that there are no objects for such subjects. This seems hard to swallow. But Nietzsche thinks otherwise. If the mark of consciousness is a conceptual vocabulary, as Nietzsche believes, it seems perfectly reasonable to think that there are no objects for subjects who are incapable of representing the world conceptually. There are no objects for those who are strictly unconscious, for example.

12 For discussion on this point, see Katsafanas (2005: 14). The constructivist view I attribute to Nietzsche, which holds that human practices bring objects into existence, is meant to include actions motivated by subconscious drives as well as reflective, conscious actions. My use of the term 'actions' instead of 'practices' in Remhof (2015a) was not sufficiently clear on this point. 'Actions' strongly suggests active, conscious, reflective behaviors, and Nietzsche does not seem to think that such behavior must exist for objects to exist. Concepts could be applied in a passive, subconscious, unreflective manner. For insightful discussion about Nietzsche's view of the relation between the unconscious and language, see Katsafanas (2005).

13 For an interesting discussion about Nietzsche's view that language is a social phenomenon, in addition to worries about such a view that can be raised from within Nietzsche's own philosophical program, see Richardson (2015).

14 For a defense of this position, see Wiggins (1980) and Gabriel (2015: 43-72). 
15 For discussion about Nietzsche's view that objects are identical to some group of properties, including interesting discussion about how Descartes, Spinoza, Leibniz, and Kant also embrace this particular understanding of objecthood, see Strawson (2015: 2025). Stawson seems to believe that Nietzsche is not a constructivist. He writes that for Nietzsche there is a 'total way [an object] concretely is, qualitywise or propertywise, uncut by discursive thought' (2015: 21).

16 One might argue that forces themselves are not constructed. For considerations that suggest otherwise, see Remhof (2015a), (2017).

17 It might be argued that some responses to objections I develop, although perfectly consistent with Nietzsche's texts, move beyond the texts. This should not be a worry. Nietzsche does not always have a final, considered view on all matters. For those who pledge strict allegiance to only what can be fully demonstrated with the corpus, consider at least some of responses below Nietzschean-they are developed with a watchful eye to what Nietzsche would most likely say, all things considered.

18 Other passages that seem to support eliminativism include HH I: 19, KSA 11:36 [23], and KSA 13:14[79]. For arguments that none, in fact, support eliminativism, see Remhof (2015a), (2017).

19 The most straightforward defense of this claim occurs in Nola (1987), (1999).

20 Nietzsche's letter to Peter Gast, March 20th, 1882.

21 The influence of Boscovich on Nietzsche is well documented in the literature. See, e.g., Stack (1981), Whitlock (1999), Poellner (1995: 48-57), Ansell-Pearson (2000), and Tones and Mandalios (2015).

22 For discussion, see Poellner (1995: 48-49).

23 For readings that attribute phenomenalism to Nietzsche, see Hussain (2004), Hill (2007). For a compelling challenge to Hussain's phenomenalist interpretation, see Clark and Dudrick (2012: 98-112).

24 For discussion, see Richardson (1996: $74 \mathrm{ff}$.$) .$

25 For discussion, see Cox (1999: 101-103).

26 Loeb's (2015) interesting reading of BGE 36 assumes that Nietzsche is against anthropomorphism tout court. As far as I can tell, however, Loeb never offers an argument for the view. Loeb (2015, note 23, cf. note 33) seems to criticize Cox (1999) for failing to understand that Nietzsche's criticism of anthropomorphism extends to naturalistic interpretations. However, the notebook passage Loeb cites to support his reading (KSA 9:11[201]) only criticizes anthropomorphic interpretations that take the world to be an 'organism' on faith, similar to faith in God. For Nietzsche, this is clearly not a naturalized interpretation of the world.

I understand naturalism simply to mean that there is no warrant for positions that cannot be confirmed by studying the natural world. For discussion about how Nietzsche's commitment to constructivism challenges some prominent readings of his naturalism, see Remhof (2015b).

28 Heidegger (1979) develops this reading of Nietzsche.

29 For an illuminating discussion, see Clark and Dudrick (2012: 54-57).

30 Does Nietzsche's view that sensory information must be taken into consideration when constructing objects suggest that there are objects given in perceptual experience that constitute the correctness conditions of intentional concept application? No: Nietzsche's texts suggest that sensory information only carries information about empirical properties and objects only come into existence once empirical properties are organized under concepts. Importantly, however, Nietzsche seems to think that perceptual experience is conceptually structured. Our sensory apparatus generates 
determinate perceptual experience partly because our sensory apparatus contains conceptual content (see KSA 11:38[10], cf. GS 57). This means that our sensory apparatus itself is representational. And Nietzsche holds that representations, such as intentional conceptual representations, can be meaningfully compared only with other representations, such as conceptually structured perceptual representations (cf. GM III: 12). It follows that we can make meaningful judgments only about material the senses transform. This explains one crucial way in which Nietzsche thinks that the nature of sense experience constrains a plausible account of object construction. Constructivists about objects do well to accept that sense experience is conceptually structured, though not fully structured into objects. Our sensory apparatus initially organizes the data we then organize into objects. For further development of these points, see Remhof (2017).

31 See, e.g., Boghossian (2006: 42-57); Ferraris (2015: 15-34).

32 For a recent discussion, see Bailey (2013).

33 Why not Schopenhauer? Elements of Schopenhauer's idealism are certainly noticeable in Nietzsche's thought. For Nietzsche, reality prior to human practices appears to be undifferentiated, and objects come into existence by virtue of applying conceptual representations to the world in experience. Similarly, in The World as Will and Representation, Schopenhauer holds that what most basically exists is undifferentiated will, and objects are just ways in which that will is empirically objectified in relation to an intellect equipped with conceptual capacities-in this case, the ability to apply the principle of sufficient reason. There are nonetheless substantial differences between the two views. The most pertinent for the current discussion is this: Schopenhauer appears to vacillate between the thinking that empirical reality is what must be actually represented by some consciousness (1958: 4-5) and what can possibly be represented by some consciousness $(1958: 5,9)$. If the former interpretation is true, then it seems impossible for objects before human beings to exist. But this is not the case if the latter interpretation is true. Nietzsche, I argue, follows Kant in embracing the latter.

34 The following reconstruction is indebted to Poellner (1995: 83-85) and Leiter (2002: 19-20).

35 Thanks to an anonymous referee for pushing me to be clear about this argument.

36 The following reading of Kant is greatly indebted to conversations with Todd Kukla and Arthur Melnick. See also Melnick (2004).

37 At least one contemporary metaphysician, Jubien (1992), holds this view. The difference between Nietzsche and Jubien is that Jubien thinks that the relata are two intrinsically individuated substances.

38 See Hoffman and Rosenkrantz (1997: 76).

39 For a defense of the idea that consciousness differentiates humans from other objects, see Merricks (2003).

40 Of course, this leaves open whether the identity conditions of human beings depend on human beings. But targeting $\mathrm{CC} 1$ renders the truth or falsity of constructivism a separate issue, since constructivism applies to objects, not human beings. Also, one might object to the idea that, on Nietzsche's account, human beings are ontologically distinct from objects. For example, he thinks that viewing human beings as unique is placing humanity in a 'false rank order in relation to animals and nature' (GS 115, see also GM III: 25). But the attributes that Nietzsche thinks lead human beings to hold such a view are those often associated with what God presumably granted human beings, such as rationality, or even Kantian pure reason. Nietzsche can deny this view while remaining committed to the view that humans are unique because they are conscious. 


\section{REFERENCES}

\section{WORKS BY NIETZSCHE, F.W.}

(1976), A Antichrist, in W. Kaufmann (ed.) and trans., The Portable Nietzsche, New York: Penguin Books (1895).

(1989), BGE Beyond Good and Evil, trans. W. Kaufmann. New York: Vintage (1886).

(1997), D Daybreak, trans. R. J. Hollingdale. Cambridge: Cambridge University Press (1881). (1989), EH Ecce Homo, trans. W. Kaufmann. New York: Vintage (1888).

(1996), HH Human, All Too Human, trans. R. J. Hollingdale. Cambridge: Cambridge University Press (1878).

(1988), KSA Kritische Studienausgabe, trans. G. Colli and M. Montinari (eds). Berlin: De Gruyter.

(1989), GM On the Genealogy of Morals, trans. W. Kaufmann. New York: Vintage (1887).

(2001), GS The Gay Science, trans. J. Nauckoff. Cambridge: Cambridge University Press $(1882,1887)$.

(1998), TI Twilight of the Idols, trans. D. Large. Oxford: Oxford University Press (1889).

(1979), TL 'On Truth and Lie in an Extra-Moral Sense', in D. Breazeale (ed.) and trans., Philosophy and Truth: Selections from Nietzsche's Notebooks of the Early 1870's. New Jersey: Humanities Press.

(1976), Z Thus Spoke Zarathustra, trans. W. Kaufmann. New York: Penguin (1883-5).

\section{WORKS BY OTHER AUTHORS}

Addis, L. (2013), Nietzsche's Ontology. Frankfurt: Ontos Verlag.

Anderson, L. (1998), 'Truth and Objectivity in Perspectivism', Synthese, 115: 1-32.

Ansell-Pearson, K. (2000), 'Nietzsche's Brave New World of Force: On Nietzsche's Time Atom Theory Fragment and the Matter of Boscovich's Influence on Nietzsche', Journal of Nietzsche Studies, 20: 5-33.

Bailey, T. (2013), 'Nietzsche the Kantian?' in K. Gemes and J. Richardson (eds) The Oxford Handbook to Nietzsche. Oxford: Oxford University Press.

Boghossian, P. (2006), Fear of Knowledge. Oxford: Oxford University Press.

Boscovich, R. (1922), A Theory of Natural Philosophy, ed. J.M. Child. Chicago: Open Court Publishing.

Braver, L. (2007), A Thing of This World: A History of Continental Anti-realism. Evanston: Northwestern University Press.

Clark, M. (1990), Nietzsche on Truth and Philosophy. Cambridge: Cambridge University Press.

Clark, M. and Dudrick, D. (2012), The Soul of Nietzsche's Beyond Good and Evil. Cambridge: Cambridge University Press.

Cox, C. (1999), Nietzsche: Naturalism and Interpretation. Berkeley: University of California Press.

Danto, A. (1965), Nietzsche as Philosopher. New York: Columbia University Press.

Doyle, T. (2009), Nietzsche on Epistemology and Metaphysics. Edinburgh: Edinburgh University Press.

Emden, C. (2014), Nietzsche's Naturalism: Philosophy and the Life Sciences in the Nineteenth Century. Cambridge: Cambridge University Press.

Ferraris, M. (2015), Introduction to New Realism. London: Bloomsbury Academic. 
Gabriel, M. (2015), Fields of Sense: A New Realist Ontology. Edinburgh: Edinburgh University Press.

Hales, S. and Welshon, R. (2000), Nietzsche's Perspectivism. Urbana: University of Illinois Press.

Heidegger, M. (1979), Nietzsche Vol. I: The Will to Power as Art. San Francisco: Harper and Row Publishers.

Hill, R. (2003), Nietzsche's Critiques: The Kantian Foundations of His Thought. Oxford: Oxford University Press.

- (2007), Nietzsche: A Guide for the Perplexed. London: Continuum Press.

Hoffman, J. and Rosenkrantz, G. (1997), Substance: Its Nature and Existence. London: Routledge.

Hussain, N. (2004), 'Nietzsche's Positivism', European Journal of Philosophy, 12/3: 326-368.

Jubien, M. (1992), Ontology, Modality, and the Fallacy of Reference. Cambridge: Cambridge University Press.

Kant, I. (1998), Critique of Pure Reason, trans. P. Guyer and A. Wood. Cambridge: Cambridge University Press.

Katsafanas, P. (2005), 'Nietzsche's Theory of Mind: Consciousness and Conceptualization', European Journal of Philosophy, 13: 1-31.

Leiter, B. (1994), 'Perspectivism in Nietzsche's Genealogy of Morals', in R. Schacht (ed.) Nietzsche, Genealogy, Morality: Essays on Nietzsche's 'On the Genealogy of Morals'. Berkeley: University of California Press.

- (2002), Nietzsche on Morality. New York: Routledge.

Loeb, P. (2015), 'Will to Power and Panpsychism: A New Exegesis of BGE 36', in M. Dries and P. Kail (eds) Nietzsche on Mind and Nature. Oxford: Oxford University Press.

Melnick, A. (2004), Themes in Kant's Metaphysics and Ethics. Washington, D.C.: Catholic University of America Press.

Merricks, T. (2003), Objects and Persons. Oxford: Oxford University Press.

Nehamas, A. (1985), Nietzsche: Life as Literature. Cambridge: Harvard University Press.

Nola, R. (1987), 'Nietzsche's Theory of Truth and Belief', Philosophy and Phenomenological Research, 48: 525-562.

— (1999), 'Nietzsche's Naturalism: Science and Belief', in B. Babette and R. Cohen (eds) Nietzsche, Epistemology, and Philosophy of Science. Dordrecht: Kluwer Academic Publishers.

Poellner, P. (1995), Nietzsche and Metaphysics. Oxford: Oxford University Press.

Remhof, J. (2015a), 'Nietzsche on Objects', Nietzsche-Studien, 44: 291-314. (2015b), 'Naturalism, Causality, and Nietzsche's Conception of Science', Journal of Nietzsche Studies, 46: 110-119.

- (2017), Nietzsche's Constructivism: A Metaphysics of Material Objects. New York: Routledge. Richardson, J. (1996), Nietzsche's System. New York: Oxford University Press.

- (2015), 'Nietzsche, Language, Community', in J. Young (ed.) Individual and Community in Nietzsche's Philosophy. Cambridge: Cambridge University Press.

Schacht, R. (2000), 'Nietzsche's Will to Power', International Studies in Philosophy, 32: 83-94.

Schopenhauer, A. (1958), in E. F. J. Payne (ed.), and trans., The World as Will and Representation, Vol. II. New York: Dover Publications Inc.

Stack, G. (2005), Nietzsche's Anthropic Circle: Man, Science, and Myth. Rochester: University of Rochester Press.

Strawson, G. (2015), 'Nietzsche's Metaphysics?' in M. Dries and P. Kail (eds) Nietzsche on Mind and Nature. Oxford: Oxford University Press.

Welshon, R. (2014), Nietzsche's Dynamic Metapsychology: This Uncanny Animal. New York: Palgrave Macmillan.

Young, J. (1992), Nietzsche's Philosophy of Art. Cambridge: Cambridge University Press. 